\title{
The relation of Leaf Area Index, Temperatures and Ultraviolet Radiation in trees areas of a city in central Chile
}

\author{
Relação entre o Índice de Área Foliar, Temperaturas e Radiação \\ Ultravioleta em áreas florestadas de uma cidade no centro do Chile
}

\author{
Ricardo Ibáñez ${ }^{1}$ (D), Mauricio Ponce-Donoso² (D), Óscar Vallejos-Barra² (D) \\ ${ }^{1}$ Corporación Nacional Forestal - CONAF, Talca, Chile \\ ${ }^{2}$ Escuela de Ingeniería Forestal, Universidad de Talca, Talca, Chile
}

\begin{abstract}
How to cite: Ibáñez, R., Ponce-Donoso, M., Vallejos-Barra, Ó. (2021). The relation of leaf area index, temperatures and ultraviolet radiation in trees areas of a city in central Chile . Scientia Forestalis, 49(129), e3170.

https://doi.org/10.18671/scifor.v49n129.02
\end{abstract}

\begin{abstract}
The relationship between leaf area index (LAI), ultraviolet radiation (UV) and temperature measured at 1.5 meters $\left(\mathrm{T}^{\circ}{ }_{1.5}\right)$ and at ground level $\left(\mathrm{T}^{\circ} \mathrm{S}\right)$ was studied, in three urban forest areas of Talca City, Chile. Circular plots with different tree projection coverage areas were defined for the registration of the $\mathrm{T}^{\circ}$ and UV data. Measurements between 13 and 14 hours were performed and distributed for each year season, while the LAI was obtained with a single record per season; the selection zones and measurement points were done by a non-probabilistic method. The results showed that LAI, as a factor, had a statistical significance effect for $\mathrm{UV}, \mathrm{T}^{\circ}{ }_{1.5}$ and $\mathrm{T}^{\circ} \mathrm{S}$, with $0.0081 ; 0.0058$ and 0.0334 respectively $(\mathrm{P}<0.05)$, demonstrating that LAI is related as indicator of the mitigating function of urban forest, regardless of season of the year. The correlations were positive, although weak, as they failed to robustly explain their relationship with the measured variables; and LAI did not fully explain the variability that it has with $\mathrm{T}^{\circ} \mathrm{S}$ and $\mathrm{T}^{\circ}{ }_{1.5}(r=0.47$ and $r=0.48$ respectively), the same for UV $(r=0.38)$. In the context studied, it was not possible to determine that the LAI is an index that explains the variability presented, obtaining $R^{2}$ of $22.15 \%, 23.28 \%$ and $14.47 \%$ for $\mathrm{T}^{\circ} \mathrm{S}, \mathrm{T}^{\circ}{ }_{1,5}$ and $\mathrm{UV}$, respectively, so the tree species and the characteristics associated with the plots, would explain the high dispersion of the results. The presence of trees favors the condition of $\mathrm{T}^{\circ}$ and UV in the city pedestrian displacements.
\end{abstract}

Keywords: Urban forest; Urban mitigation; Ecosystem services; Tree mitigation; Urban planning.

\section{Resumo}

Estudou-se a relação entre índice de área foliar (LAI), radiação ultravioleta (UV) e temperatura a 1,5 metros $\left(\mathrm{T}^{\circ}{ }_{1,5}\right)$ e ao nível do solo $\left(\mathrm{T}^{\circ} \mathrm{S}\right)$, em três áreas arborizadas da Cidade de Talca, Chile. Para o registro dos dados definiu-se parcelas circulares com diferentes áreas de cobertura de projeção de árvores, a $T^{\circ}$ e UV, que foram medidos entre $13 \mathrm{~h}$ e $14 \mathrm{~h}$, distribuídos para cada estação do ano, enquanto o IAF foi obtido com um único registro por estação; as zonas de seleção e os pontos de medição foram realizados por um método não probabilístico. Os resultados mostraram que o IAF, como fator, teve um efeito estatisticamente significante para UV, $\mathrm{T}^{\circ}{ }_{1,5}$ e $\mathrm{T}^{\circ} \mathrm{S}$, com 0,$0081 ; 0,0058$ e 0,0334 , respectivamente $(P<0,05)$, demonstrando que o IAF está relacionado como um indicador da função mitigadora da arborização urbana, independentemente da estação do ano. Suas correlações foram positivas, embora fracas, uma vez que não conseguiram explicar de forma robusta sua relação com as variáveis medidas, visto que o IAF não explicou totalmente a variabilidade que tem $\mathrm{T}^{\circ} \mathrm{S}$ e $\mathrm{T}^{\circ} 1,5(r=0,47$ e $r=0,48$ respectivamente); e o mesmo para UV $(r=0,38)$. Para o contexto estudado, não foi possível determinar que o IAF seja um índice que explica a variabilidade apresentada pelas variáveis medidas, obtendo-se $\mathrm{R}^{2}$ de $22,15 \%, 23,28 \%$ e

Financial support: None

Conflict of interest: Nothing to declare.

Correspondig author: mponce@utalca.cl

Received: 22 October 2018.

Accepted: 26 May 2020

Editor: Paulo Henrique Müller Silva.

(c) (i) This is an Open Access article distributed under the terms of the Creative Commons Attribution License, which permits unrestricted use, distribution, and reproduction in any medium, provided the original work is properly cited. 
14,47\% para $\mathrm{T}^{\circ} \mathrm{S}, \mathrm{T}^{\circ} 1,5$ e UV, respectivamente, de modo que as espécies arbóreas e as características associadas às parcelas explicariam a alta dispersão dos resultados. A presença de árvores favorece a condição de $T^{\circ}$ e UV nas vias de pedestres da cidade.

Palavras-Chave: Árvores urbanas; Mitigação urbana; Serviços ecossistêmicos; Mitigação de árvores; Planejamento urbano.

\section{INTRODUCTION}

The planning of urban green spaces systems defines what tree species will be used (i.e. gardens, parks, squares, grove, pedestrian and others). Thus, its distribution and quantity within the city depends on the space available and how people choose to occupy this place with herbaceous plants, shrubs or trees (Rowntree, 1998). The vegetation (trees, bushes and grass) influence the environment; in trees the species, composition, size, diameter, height, biomass and leaf area and others are the main variables (Armson et al., 2013; Bochaca et al., 2013; Pudjowati et al., 2013; Heisler et al., 2014; Colunga et al., 2015; Coronel et al., 2015; Elmes et al., 2017; Sanusi et al., 2017; Tang et al., 2017). The knowledge of these variables can be used for the urban green spaces system planning, as well as for the determination of tree value (Ponce-Donoso et al., 2017; Endreny, 2018).

Global warming has increased the planet's temperature, challenging the search for solutions to thermally regulate cities. The vegetation and especially trees are effective contributors to the urban climate, since they help to reduce the negative effects on people, such as the different types of pollution, radiation or acoustics, among others (Armson et al., 2013; Elmes et al., 2017). Together with other factors, particulate matter fulfills the functions of pollution mitigation (McDonald et al., 2007; Irga et al., 2015); provides shade (Smargiassi et al., 2009), mitigates the effect of heat islands (Hardin \& Jensen, 2007; Armson et al., 2013; Tang et al., 2017), reduces ultraviolet radiation and temperature, especially where the ozone layer has decreased (Grant et al., 2002; Heisler et al., 2014). It also mitigates noise (Pudjowati et al., 2013), determines microclimates (Colunga et al., 2015; Coronel et al., 2015) improving relative humidity, whose gradients and oscillations depend on gray and green infrastructure (Bowler et al., 2010). Therefore, the management of urban trees, especially those located in spaces for public use, is relevant in public policies, especially considering the process of climate change currently experienced worldwide.

Temperature is usually one of most sensitive meteorological variables to urbanization processes, registering higher values in the center of cities compared to natural environment; this occurs as a result of the replacement of green spaces, rural areas and its interface with urban areas' gray infrastructure (Hardin \& Jensen, 2007). In this context, tree-lined streets and green areas offer better environmental conditions, since they delay night cooling (Bochaca et al., 2013), because leaves and branches reduce both solar and UV radiation (De Oliveira et al., 2013), while the temperature of the earth's surface increases with the decrease of tree canopy (Ponce-Donoso et al., 2020).

The leaves of trees and foliar area are important parameters, not only for the study of various physiological processes such as photosynthesis, transpiration, evapotranspiration and productivity (Moser et al., 2007; Olivas et al., 2013), but also in the planning of cities, aiming to mitigate the effect of urban heat islands (Hardin \& Jensen, 2007). The way in which an urban forest can modify the local microclimate in pedestrian traffic can vary according to the design and type of tree species, key characteristics such as the type, angle and size of leaves, canopy architecture or simply its density (Sanusi et al., 2017).

A way to measure the structure of canopy is through the Leaf Area Index (LAl), which is a dimensionless variable, defined as a numerical expression as half the total intercepting area per unit ground surface area (Chen \& Black, 1992); or as a projected leaf area in order to take into account the irregular form of needles and leaves (Jonckheere et al., 2004). The canopy structure corresponds to the shape, surface, distribution and spatial arrangement of tree aerial organs, therefore LAl depends on tree morphology, leaves' orientation and distribution; hence trees of different species have values other than LAI (Jonckheere et al., 2004). 
The use of hemispheric photographs allows LAI to be determined, since it provides an ascending view of all parts of the sky, based on the quantification of the geometry of the visible and obstructed sky (Weiss et al., 2004). This technique allows to calculate solar radiation regimes and canopy characteristics of a tree, such as the distribution of leaves angles and light interception (Rich, 1990).

The LAl varies in time and space due to seasonal variations (Gao et al., 2013), which is also influenced by a variety of factors, such as the species growth, the changes caused by the development of the trees' area, architecture, climatic conditions (Dermody et al., 2007; Meier \& Leuschner, 2008) and soil properties (Oztürk et al., 2014).

Given the importance of the influence for green infrastructure to urban population, it is necessary to know how the location of woodland influences different environmental variables, which then allow improving the habitability condition of the population in the cities.

In the same sense, the location trees in urban context should not be a trivial, since their influence on environmental variables could have a positive impact on the population, on variables such as $\mathrm{T}^{\circ}$ and UV. Therefore planning of urban green systems, parks, streets or squares, the intentionality of urban design and what should be planted can be improved. Thus, the aim of the present article was to relate Leaf Area Index (LAI) to the environmental variables of temperature and UV radiation, considering the influence that tree cover has on the displacement of city inhabitants through the different pedestrian paths available.

\section{MATERIALS AND METHODS}

The study area was Talca City, located in Maule Region, Chile. It is characterized by being in a transition area between arid-semiarid climates of northern and cold and rainy climates of southern zones, and has a temperate Mediterranean climate (Centro de Investigación y Transferencia en Riego y Agroclimatología, 2005). The city is located at an altitude of $102 \mathrm{~m}$ above the sea level, latitude $35^{\circ} 25^{\prime} 59^{\prime \prime}$ South, longitude $71^{\circ} 40^{\prime} 00^{\prime \prime}$ West and $232 \mathrm{~km}^{2}$ covers a total area (Biblioteca del Congreso Nacional, 2013). The population is of 220,357 inhabitants (INE, 2017).

The average temperature is $14.2^{\circ} \mathrm{C}$, the value of the UV index during winter fluctuates between 1 and 3, which is considered low, while in summer it varies between 9 and 10, considered a very high value. The average exposure to the sun per day in January is 11.6 hours and in June 2.5 hours (Centro de Investigación y Transferencia en Riego y Agroclimatología, 2005). The green areas in the city grew from 4.2 in 2007 to 5.8 square meters per person in 2016 (Plan de Desarrollo Comunal, 2017).

The data was collected in urban spaces, defined and distributed in a circuit of streets in the center of the city, being located in places of public use and high pedestrian circulation were located in three avenues of the city center, called Zone, chosen for their important pedestrian and motorized traffic, commercial, labor and recreation (Figure 1). The scale used was considered appropriate when compared to the Escobedo and Nowak (2009) study. The selection zones and measurement points were done by a nonprobabilistic, directed and intentional sampling; they comprised a selection of population units through personal judgment (Ávila, 2006). 30 circular plots with a radius of eight meters were defined for sampling (equivalent to $201 \mathrm{~m}^{2}$ ). In each of them, 10 plots were distributed, each one having a different tree projection coverage area where the measurements were made:

- Zone I: comprises Alameda Avenue between 3 Oriente and 4 Poniente streets. This section corresponds to an important urban forest area. It is located in the central city area and serves as the main communication artery that extends for 20 blocks. The Alameda is a double track avenue that is widely used by motorists and emergency vehicles. During the past seven years it has gained commercial importance with new buildings such as hotels, public and private edifices, playgrounds for children, educational establishments, clinical centers, restaurants and recreation places and 
others. It concentrates a great number of arboreal species, some over 80 years old that are located in the central dividing belt of the avenue. It comprises six blocks (plots T01 to T10, Figure 2a).

- Zone II: comprises Isidoro del Solar Avenue plus two plots located in Armas Square. The avenue has a small central reservation where there are several trees. It is a street that connects the Armas Square with Alameda in both directions of traffic and has a center sidewalk with Robinia spedoacacia L. trees and mainly large Platanus $x$ hispanica Mill specimens; in the square there are different restaurants and pubs, and small professional office buildings. It comprises five blocks (plots T11 to T20, Figure $2 b$ ).

- Zone III: comprises Uno Sur Street between 1 Poniente and 7 Oriente streets. It is the main commercial area of city and has an extension of eleven streets and most of the stores are of one floor, although there are a few buildings that exceed two floors and present a scarce presence of mainly Lagerstroemia indica (L) Pers. trees. This Zone has three pedestrian streets and comprises seven blocks (plots T21 to T30, Figure 2c).

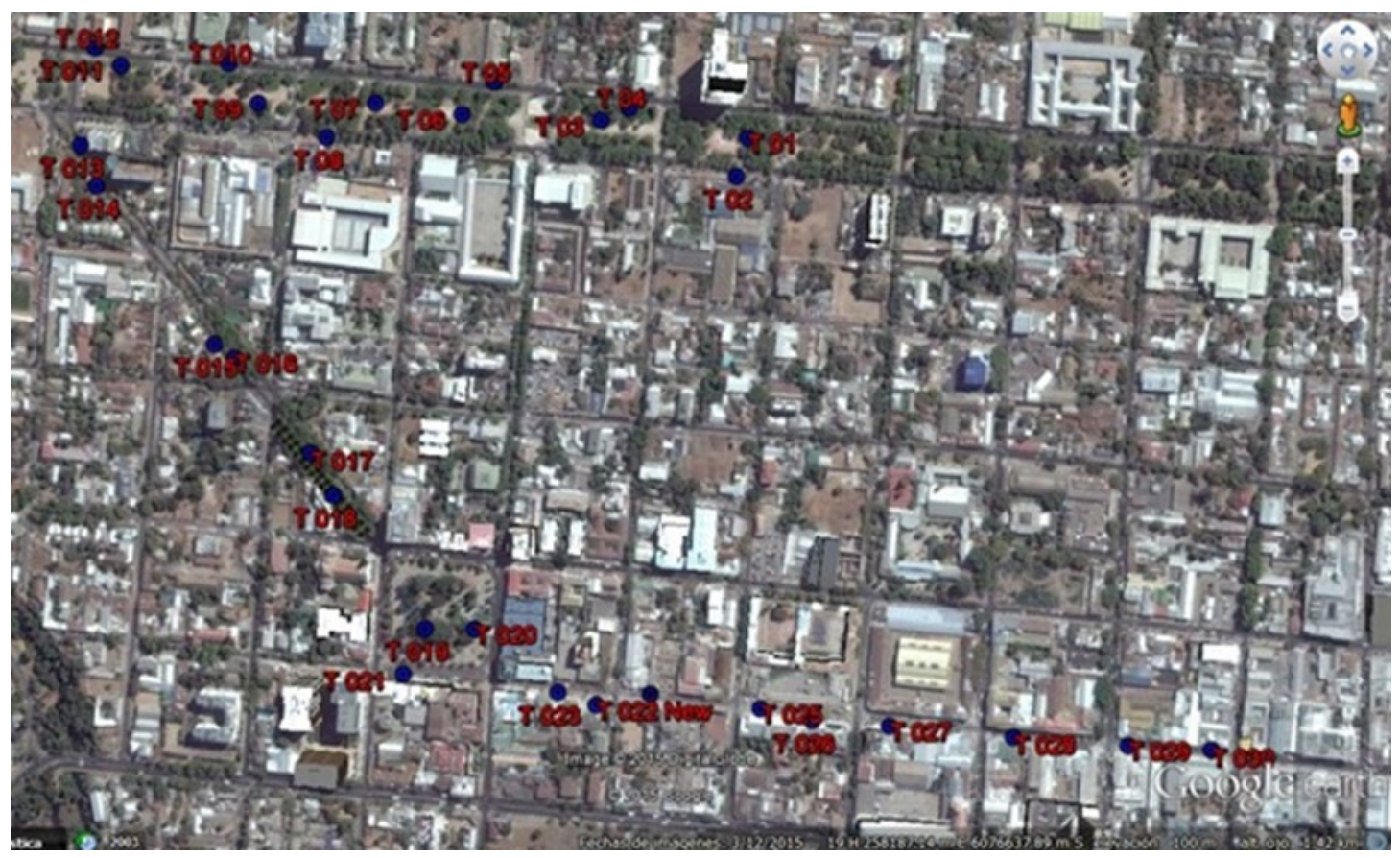

Figure 1. Image of streets and location of the plots

The data of ultraviolet radiation and two temperatures were collected between 13:00 to 14:00 hours; during 8 days in each season ( 2 days a week). The first one was between December 2014 to January 2015, called summer; the second, April and May 2015, called autumn; the third, September and November 2015, called spring, and fourth, August and September 2016, called winter. Those data was recorded at two points in each plot; one in the center and the other in its periphery in different orientations. For analysis the average of the records of each season was used, totaling 960 data, distributed in 30 plots and three zones, 720 records of temperature, plus 240 data of LAl obtained for each of the two points of the plot, .

The LAI was measured in 2016 only once per season in each plot, in the center and one point of the perimeter. For the summer period it was January 15, autumn on May 13, winter on September 7 and spring on November 21. The measurements were made with the following instruments: Thermometer-Hygrometer JT-07CRL for temperature, UV Light Meter UV340B for UV radiation and the Cl-110 Plant Canopy Imager@ for LAI. 


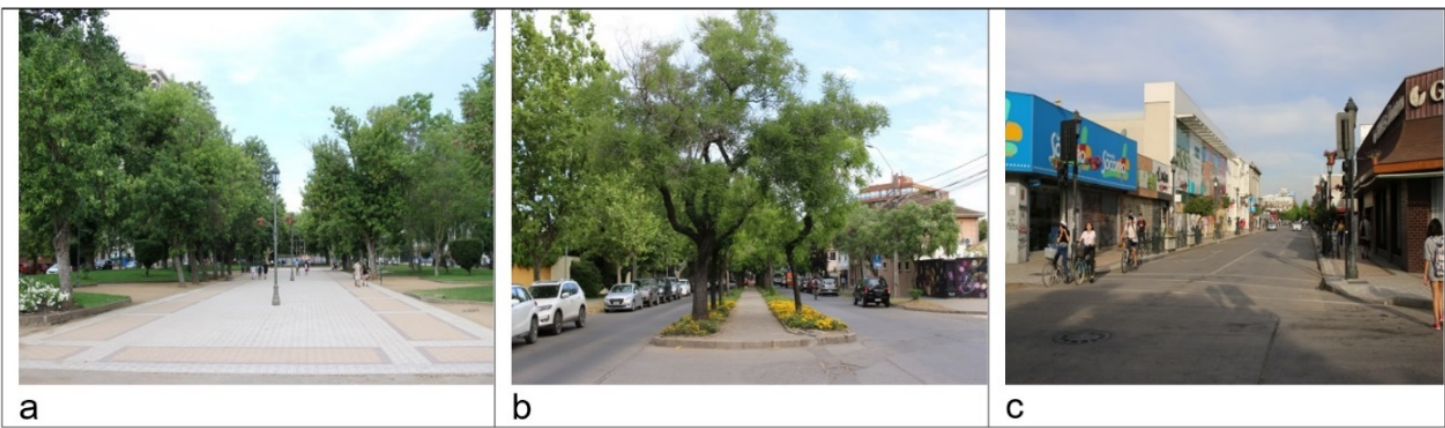

Figure 2. General views of different zones. a. Zone I; b. Zone II and c. Zone III

Normality assumptions were verified through the Kolmogorov-Smirnov test $(p<0.05)$ for normality and Levene's test $(p<0.05)$ for homoscedasticity, not being fulfilled for the first and fulfilled for the second (Márquez, 1997). Where the normality assumption was not fulfilled, Kruskal-Wallis's non-parametric analysis (K-W) was used to identify significant statistical differences; K-W showed there were no significant differences found in both environmental variables ( $\mathrm{T}^{\circ}$ and $\mathrm{UV}$ ) with respect to the LAI values recorded. In addition, a simple regression was performed between each environmental variable and the LAI as a factor, with the purpose of knowing the correlation and the coefficient of determination $\left(R^{2}\right)$, which expresses the correlation between the data of the independent variable (LAl) and their respective dependent variables (temperature and UV variables). Statistical analysis was performed with STATGRAPHICS ${ }^{\circledR}$ Centurion XVI (Statpoint Technologies INC, 2010).

\section{RESULTS AND DISCUSSION}

Data showed a high amplitude in the records (Table 1), evidenced mainly by its dispersion, which is influenced by urban tree coverage, season of year, surrounding vegetation, nearby constructions, temperature record schedule, atmospheric condition, types of instruments used and points of measurement for those that were recorded according to the plot and not under the tree; an aspect which differs from other studies (Hardin \& Jensen, 2007; Oztürk et al., 2015; Tang et al., 2017).

The highest records in both temperatures and UV were obtained in Zone III, which corresponds to an area with scarce vegetation when compared to the other Zones, which would explain the lesser mitigation of these variables in Zone III, confirming the presence of an urban heat island (Martínez, 2017).

The temperature showed expected values, lower in winter and higher in summer, typical of the climate study area. The soil temperature at $1.5 \mathrm{~m}$ reached values higher at ground level, but no significant differences between plots was found, with a similar situation for UV. This was due to the fact that measurements were made under different canopy covers, simulating random displacement of pedestrians through the city. The records were also influenced by different types of surfaces; for example, in Zone I and II there are more plots with grass or soil, while in Zone III they were only located on cement or tiles. Lower temperature values were recorded when high LAl registers were obtained, confirming the mitigation function of the vegetation in relationship to thermal comfort in the city (Oztürk et al., 2015; Elmes et al., 2017).

The LAl fluctuated between 0.54 and 5.29 under the different tree coverages. Plots 7 and 19 are the only ones that are under cover of an evergreen species (Peumus boldus Mol.), LAI average was 2.17 and 4.13 respectively; these values were consistently higher during the year in comparison to other plots, which are mainly composed of deciduous trees, showing the influence of tree cover in LAI determination (Jonckheere et al., 2004; Pokorný et al., 2008; De Oliveira et al., 2013). 
Table 1. Summary of the environmental variables by Zone and season

\begin{tabular}{|c|c|c|c|c|c|c|c|}
\hline \multirow{2}{*}{ Season } & \multirow{2}{*}{ Zone } & \multicolumn{3}{|c|}{ Ground Temperature } & \multicolumn{3}{|c|}{ Temperature $1.5 \mathrm{~m}$} \\
\hline & & Median & Average & Amplitude & Median & Average & Amplitude \\
\hline \multirow{3}{*}{ Autumn } & I & 19.5 & 19.4 & $17.8-20.8$ & 19.2 & 19.2 & $17.9-21.5$ \\
\hline & II & 18.0 & 18.3 & $16.1-21.1$ & 17.9 & 18.0 & $16.4-19.8$ \\
\hline & III & 23.2 & 22.5 & $19.1-27.9$ & 21.5 & 21.5 & $19.5-24.7$ \\
\hline \multirow{3}{*}{ Winter } & 1 & 16.6 & 16.8 & $15.1-18.4$ & 16.5 & 16.7 & $15.0-18.3$ \\
\hline & II & 14.6 & 14.6 & $12.9-16.4$ & 14.5 & 14.5 & $12.8-16.3$ \\
\hline & III & 16.6 & 16.6 & $14.9-19.2$ & 16.4 & 16.4 & $14.8-18.9$ \\
\hline \multirow{3}{*}{ Spring } & I & 23.7 & 24.3 & $22.1-28.4$ & 22.6 & 22.7 & $18.3-25.1$ \\
\hline & II & 23.6 & 24.1 & $21.3-27.5$ & 23.3 & 23.3 & $21.5-27.0$ \\
\hline & III & 26.1 & 26.4 & $23.0-31.4$ & 24.2 & 24.6 & $22.6-27.7$ \\
\hline \multirow{3}{*}{ Summer } & I & 32.1 & 32.4 & $27.9-39.7$ & 29.4 & 29.4 & $27.5-31.9$ \\
\hline & II & 32.5 & 33.8 & $29.3-42.8$ & 31.6 & 32.3 & $30.4-37.4$ \\
\hline & III & 35.2 & 34.8 & $27.1-39.6$ & 29.4 & 29.6 & $27.1-32.9$ \\
\hline \multirow{2}{*}{ Season } & & \multicolumn{3}{|c|}{ UV Radiation } & \multicolumn{3}{|c|}{ LAI } \\
\hline & & Median & Average & Amplitude & Median & Average & Amplitude \\
\hline \multirow{3}{*}{ Autumn } & I & 141.7 & 142.7 & $104.0-295.1$ & 1.1 & 1.2 & $0.5-2.7$ \\
\hline & II & 130.3 & 126.5 & $9.1-297.7$ & 1.5 & 1.9 & $0.6-4.7$ \\
\hline & III & 222.6 & 194.2 & $154.5-316.9$ & 1.0 & 1.1 & $0.5-2.0$ \\
\hline \multirow{3}{*}{ Winter } & 1 & 220.2 & 213.9 & $35.0-252.8$ & 1.0 & 1.2 & $0.3-2.7$ \\
\hline & ॥ & 219.1 & 207.8 & $9.0-217.7$ & 1.0 & 1.4 & $0.5-5.3$ \\
\hline & III & 235.2 & 237.4 & $42.9-255.5$ & 1.0 & 1.5 & $0.8-4.0$ \\
\hline \multirow{3}{*}{ Spring } & । & 338.8 & 755.2 & $79.1-2,665.8$ & 2.1 & 2.2 & $1.4-3.2$ \\
\hline & II & 320.1 & 431.0 & $17.0-1,331.2$ & 2.1 & 2.2 & $1.3-4.4$ \\
\hline & III & 772.2 & 759.3 & $96.5-1,524.8$ & 1.2 & 1.4 & $0.7-2.8$ \\
\hline \multirow{3}{*}{ Summer } & I & 153.5 & $2,123.7$ & $90.6-7,735.0$ & 2.1 & 2.4 & $0.6-5.0$ \\
\hline & II & 515.0 & $1,577.6$ & $125.0-7,600.0$ & 2.5 & 2.7 & $1.2-4.6$ \\
\hline & III & $3,532.5$ & $2,735.1$ & $83.8-5,240.0$ & 3.4 & 3.0 & $1.3-4.7$ \\
\hline
\end{tabular}

UV radiation in the year reached low values in winter (9.3 to 316.9) and high in summer (226.5 to 7,735.0). The high values of UV were related to low LAI values, that is, a greater tree coverage reduces UV radiation (Hardin \& Jensen, 2007; De Oliveira et al., 2013; Olivas et al., 2013), an aspect that was especially observed during spring and summer periods.

The variance analysis showed that LAI (Table 2), as a factor, had a significant different effect ( $p<0.05$ ) on both temperatures and UV, confirming the relationship between LAI and registered climatic variables (Hardin \& Jensen, 2007; Armson et al., 2013; De Oliveira et al., 2013; Oztürk et al., 2015; Tang et al., 2017).

Table 2. Variance analysis

\begin{tabular}{cccc}
\hline Variable Factor & Ground $\mathbf{T}^{\circ}\left({ }^{\circ} \mathbf{C}\right)$ & $\mathbf{T}^{\circ} \mathbf{1 , 5} \mathbf{~ m}\left({ }^{\circ} \mathbf{C}\right)$ & UV Radiation UV \\
\hline LAl & 0.0081 & 0.0058 & 0.0334 \\
\hline
\end{tabular}

Non-linear regression models showed the best correlation (Table 3). The average values obtained were $0.47 ; 0.48$ and 0.43 for ratios of LAl to ground temperature, temperature $1.5 \mathrm{~m}$ and UV radiation, respectively. The data variability, attributed to different types of precipitation or irrigation carried out prior to measurement of climatic variables, would explain in part the presence of plots with low LAl values and lower temperatures, as pointed out by Chávez et al. (2012).

Table 3. Pearson correlation and determination coefficients

\begin{tabular}{cccccccccc}
\hline & \multicolumn{2}{c}{ Temperature } & & \multicolumn{2}{c}{ Temperature $\mathbf{1 . 5} \mathbf{~ m}$} & & \multicolumn{2}{c}{ UV Radiation } \\
\cline { 2 - 3 } & Pearson & $\mathbf{R}^{\mathbf{2}} \mathbf{( \% )}$ & & Pearson & $\mathbf{R}^{\mathbf{2}} \mathbf{( \% )}$ & & Pearson & $\mathbf{R}^{\mathbf{2}} \mathbf{( \% )}$ \\
\hline Center-Periphery & 0.47 & 22.15 & & 0.48 & 23.28 & & 0.38 & 14.47 \\
Center & 0.43 & 18.42 & & 0.45 & 20.18 & & 0.57 & 32.01 \\
Periphery & 0.51 & 26.09 & & 0.51 & 26.05 & & 0.34 & 11.84 \\
\hline
\end{tabular}


The correlation coefficient between LAl and temperatures showed a positive relationship, but not enough to be considered of high correlation values ( 0.47 and 0.48 respectively). A similar result to that obtained by Tang et al. (2017) who obtained a correlation value of 0.56 with respect to temperature; which in both cases are lower than those reported by Hardin and Jensen (2007) and Oztürk et al. (2015), who obtained correlation coefficients of 0.74 and 0.80 respectively. However, the design of this study is based on plots and not on an individual tree, so reported coefficients can be considered acceptable.

Positive correlation between UV and LAI was obtained, although insufficient to be considered of high value (0.38). When analyzing data according to their position in plot, those in the center showed a greater correlation with respect to periphery, with 0.56 and 0.34 respectively. As for the models adjusted by simple regression, both for ground level temperature (Figure 3a), and temperature at 1.5 meters (Figure $3 b$ ), reached the best correlation with logarithmic models, while for UV radiation (Figure $3 c$ ) it was the inverse model $Y$ square $X$.

Data dispersion showed that the relationship between LAI and environmental variables did not follow a linear model, which will be due to variability of records during the year. These results are similar to studies of the same nature, where Tang et al. (2017) pointed out that LAI explains 32\% of variation in temperature, a value higher than that obtained in this study, explained by the fact that only 36 measurements were used, while in this study they were 240.

The factors that influence the results would be the method of measuring the variables and the time required to do so. In this study, the temperature was obtained in any plots of each Zone, unlike Hardin \& Jensen (2007) who obtained them from satellite images, using thermal infrared (TIR) and achieving a correlation of 0.78 between temperature and LAI and a coefficient of determination of 62\%. Likewise, Oztürk et al. (2015) also obtained a high correlation and determination between the LAI and some environmental variables, but by using significantly lower records, with data from the same season of the year, which reduces the variability as in this this study.

The results obtained in this study are similar to those of Klingberg et al. (2017) indicating that individual urban trees have a higher LAI value than the trees of a stand, although in this case the LAI measurement was not specifically the tree, but the area of pedestrian traffic which the tree influences. However, an additional study involving the same species in both contexts could be necessary to analyze the influence of these conditions.

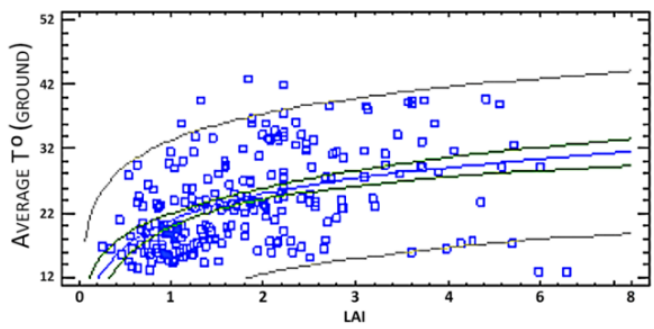

a)

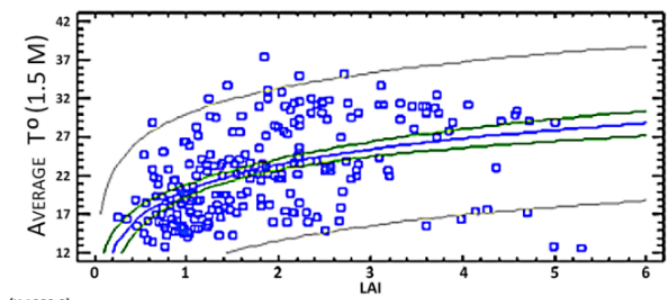

b)

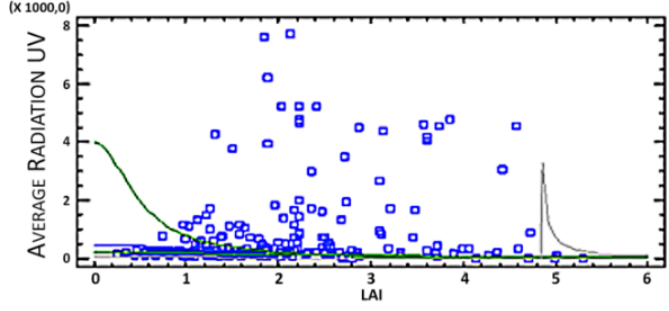

c)

Figure 3. Adjusted models Charts: a) Ground Temperature v/s LAl, b) Temperature $1.5 \mathrm{~m}$ v/s LAI and c) UV Radiation v/s LAI 


\section{CONCLUSIONS}

The urban trees with different levels of coverage act as a mitigating agent for both temperature and UV radiation, regardless of measurement point in plot, Zone and season of the year.

The soil temperature showed higher values compared to 1.5 meter, which fluctuated between $12.9^{\circ} \mathrm{C}$ to $42.8^{\circ} \mathrm{C}$ and $12.8^{\circ} \mathrm{C}$ to $37.4^{\circ} \mathrm{C}$ respectively; while LAl values fluctuated according to the vegetative period of the tree: highest in spring summer, with an average value of 2.3 and lower in autumn winter with an average of 1.38 .

The environmental variables showed a statistically significant relationship with respect to LAl, giving positive but weak correlations; showing that LAI does not fully explain the variability of temperature and ultraviolet radiation in the city studied.

\section{ACKNOWLEDGMENTS}

The authors thank the Ministerio del Medio Ambiente of Chile for the financing of Project NAC-I-035-2014: “Contribución del arbolado urbano a la mitigación del cambio climático. Medición de las principales variables", which allowed the realization of this study.

\section{REFERENCES}

Armson, D., Rahman, M., \& Ennos, R. (2013). A Comparison of the shading effectiveness of five different street tree species in Manchester, UK. Journal of Arboriculture, 39(4), 157-164.

Ávila, H. (2006). Introducción a la metodología de la investigación (175р.). Guadalajara, México: Universidad de Guadalajara.

Biblioteca del Congreso Nacional - BCN. (2013). Reportes Estadísticos Distritales y Comunales 2013. Retrieved in 2016 September 7, from http://reportescomunales.bcn.cl/2015/index.php/Talca

Bochaca, F., Puliafito, S., \& Allende, D. (2013). Mitigación de la isla de calor urbana en ciudades de zonas áridas. Proyecciones (Antofagasta), 11(2), 30-43.

Bowler, D., Buyung-Ali, L., Knight, T. M., \& Pullin, A. S. (2010). Urban greening to cool towns and cities: A systematic review of the empirical evidence. Landscape and Urban Planning, 97(2), 147-155. http://dx.doi.org/10.1016/j.landurbplan.2010.05.006.

Chávez, J., Gowda, P., Howell, T., Garcia, L., Copeland, K. S., \& Neale, C. M. U. (2012). ET mapping with high-resolution airborne remote sensing data in an adventive semiarid environment. Journal of Irrigation and Drainage Engineering, 138(5), 416-423. http://dx.doi.org/10.1061/(ASCE)|R.19434774.0000417.

Chen, J. M., \& Black, T. A. (1992). Defining leaf area index for non-flat leaves. Plant, Cell \& Environment, 4(4), 421-429. http://dx.doi.org/10.1111/j.1365-3040.1992.tb00992.x.

Centro de Investigación y Transferencia en Riego y Agroclimatología - CITRA. (2005). Resumen de datos meteorológicos de Talca. Retrieved in 2016, September 7, from http://www.citrautalca.cl/html/agroclimatologia/ resumen_datos_meteorologicos_talca.html

Colunga, M. L., Cambrón-Sandoval, V. H., Suzán-Azpiri, H., Guevara-Escobar, A., \& Luna-Soria, H. (2015). The role of urban vegetation in temperature and heat island effects in Querétaro city, México. Atmosfera, 28(3), 205-218. http://dx.doi.org/10.20937/ATM.2015.28.03.05.

Coronel, A. S., Feldman, S. R., Jozani, E., Facundo, K., Piacentini, R. D., Dubbeling, M., \& Escobedo, F. (2015). Effects of urban green areas on air temperature in a medium-sized Argentinian city. Environmental Sciences (Ruse), 2(3), 803-826.

De Oliveira, A., Albuquerque, C., Sanches, L., \& De Souza, J. (2013). Variáveis meteorológicas e cobertura vegetal de espécies arbóreas em praças urbanas em Cuiabá, Brasil. Revista Brasileira de Meteorologia, 28(4), 389-400. http://dx.doi.org/10.1590/S0102-77862013000400005.

Dermody, O., Weltzin, J., Engel, E., Allen, P., \& Norby, R. (2007). How do elevated $\left[\mathrm{CO}_{2}\right]$ warming, and reduced precipitation interact to affect soil moisture and LAI in an old field ecosystem? Plant and Soil, 301(1-2), 255-266. http://dx.doi.org/10.1007/s11104-007-9443-x.

Elmes, A., Rogan, J., Williams, C., Ratick, S., Nowak, D., \& Martin, D. (2017). Effects of urban tree canopy loss and land surface temperature magnitude and timing. ISPRS. ISPRS Journal of Photogrammetry and Remote Sensing, 128, 338-353. http://dx.doi.org/10.1016/j.isprsjprs.2017.04.011. 
Endreny, T. (2018). Strategically growing the urban forest will improve our world. Nature Communications, 9(1), 1160. PMid:29563541. http://dx.doi.org/10.1038/s41467-018-03622-0.

Escobedo, F. J., \& Nowak, D. J. (2009). Spatial heterogeneity and air pollution removal by an urban forest. Landscape and Urban Planning, 90(3-4), 102-110. http://dx.doi.org/10.1016/j.landurbplan.2008.10.021.

Gao, Y., Giese, H., Brueck, H., Yang, H., \& Li, Z. (2013). The relation of biomass production with leaf traits varied under different land-use and precipitation conditions in an Inner Mongolia steppe. Ecological Research, 28(6), 1029-1043. http://dx.doi.org/10.1007/s11284-013-1086-1.

Grant, R. H., Heisler, G. M., \& Gao, W. (2002). Estimation of pedestrian level UV exposure under trees. Photochemistry and Photobiology, 75(4), 369-376. PMid:12003126. http://dx.doi.org/10.1562/00318655(2002)075<0369:EOPLUE>2.0.CO;2.

Hardin, P., \& Jensen, R. (2007). The effect of urban leaf area on summertime urban surface kinetic temperatures: A Terre Haute case study. Urban Forestry \& Urban Greening, 6(2), 63-72. http://dx.doi.org/10.1016/j.ufug.2007.01.005.

Heisler, G., Na, H., \& Nowak, D. (2014). Modelling of urban trees effects on reducing human exposure to UV radiation in Seoul, Korea. Urban Forestry \& Urban Greening, 13(4), 785-792. http://dx.doi.org/10.1016/j.ufug.2014.05.009.

Instituto Nacional de Estadísticas - INE. (2017). Censo 2017 - Síntesis de Resultados. Retrieved in 2018, January 03, from http://www.censo2017.cl/

Irga, P. J., Burchett, M. D., \& Torpy, F. R. (2015). Does urban forestry have a quantitative effect on ambient air quality in an urban environment? Atmospheric Environment, 120, 173-181. http://dx.doi.org/10.1016/j.atmosenv.2015.08.050.

Jonckheere, I., Fleck, S., Nackaerts, K., Muys, B., \& Coppin, P. (2004). Methods for leaf area index determination Part I: Theories, techniques and instruments. Agricultural and Forest Meteorology, 121(1-2), 19-35. http://dx.doi.org/10.1016/j.agrformet.2003.08.027.

Klingberg, J., Konarska, J., Lindberg, F., Johansson, L., \& Thorsson, S. (2017). Mapping leaf area of urban greenery using aerial LiDAR and ground-based measurements in Gothenburg, Sweden. Urban Forestry \& Urban Greening, 26, 31-40. http://dx.doi.org/10.1016/j.ufug.2017.05.011.

Márquez, M. (1997). Estadística básica, un enfoque no paramétrico (40р.). Ciudad de México, México: Ediciones Universidad Autónoma de México.

Martínez, R. (2017). Contribución de los espacios arbolados a la reducción de las islas de calor urbanas: casos de la plaza Cienfuegos y el paseo peatonal de la ciudad de Talca (Memoria para optar el título de Ingeniero Forestal). Facultad de Ciencias Forestales, Universidad de Talca, Maule, Chile. 96 p.

McDonald, A. G., Bealey, W. J., Fowler, D., Dragosits, U., Skiba, U., Smith, R. I., Donovan, R. G., Brett, H. E., Hewitt, C. N., \& Nemitz, E. (2007). Quantifying the effect of urban tree planting on concentrations and depositions of PM10 in two UK conurbations. Atmospheric Environment, 41(38), 8455-8467. http://dx.doi.org/10.1016/j.atmosenv.2007.07.025.

Meier, I., \& Leuschner, C. (2008). Leaf size and leaf area index in Fagus sylvatica forests: competing effects of precipitation, temperature and nitrogen availability. Ecosystems (New York, N.Y.), 11(5), 655669. http://dx.doi.org/10.1007/s10021-008-9135-2.

Moser, G., Hertel, D., \& Leuschner, C. (2007). Altitudinal change in LAl and stand leaf biomass in tropical montane forests: a transect study in Ecuador and a Pan-Tropical meta-analysis. Ecosystems (New York, N.Y.), 10(6), 924-935. http://dx.doi.org/10.1007/s10021-007-9063-6.

Olivas, P. C., Oberbauer, S. F., Clark, D. B., Clark, D. A., Ryan, M. G., O’Brien, J. J., \& Ordoñez, H. (2013). Comparison of direct and indirect methods for assessing leaf area index across a tropical rainforest landscape. Agricultural and Forest Meteorology, 177, 110-116. http://dx.doi.org/10.1016/j.agrformet.2013.04.010.

Oztürk, M., Bolat, I., \& Ergun, A. (2014). Transforming Pinus pinaster forest to recreation site: preliminary effects on LAI, some forest floor, and soil properties. Environmental Monitoring and Assessment, 186(4), 2563-2572. PMid:24306444. http://dx.doi.org/10.1007/s10661-013-3560-1.

Oztürk, M., Bolat, I., \& Ergun, A. (2015). Influence of air-soil temperature on leaf expansion and LAI of Carpinus betulus trees in a temperate urban forest patch. Agricultural and Forest Meteorology, 200, 185-193. http://dx.doi.org/10.1016/j.agrformet.2014.09.014.

Plan de Desarrollo Comunal - PLADECO. (2017). Plan de Desarrollo Comunal 2017-2020 (180 p.). Talca. Chile: PLADECO. 
Pokorný, R., Tomášková, l., \& Havránková, K. (2008). Temporal variation and efficient of leaf area index in Young mountain Norway spruce stand. European Journal Research, 127(5), 359-367. http://dx.doi.org/10.1007/s10342-008-0212-z.

Ponce-Donoso, M., Vallejos-Barra, O., \& Escobedo, F. J. (2017). Appraisal of urban trees using twelve valuation formulas and two appraiser groups. Arboriculture \& Urban Forestry, 43(2), 72-82.

Ponce-Donoso, M., Vallejos-Barra, O., Ingram, B., \& Daniluk-Mosquera, G. (2020). Urban trees and environmental variables relationships in a city of central Chile. Arboriculture \& Urban Forestry, 46(2), 84-95. http://dx.doi.org/10.48044/jauf.2020.007.

Pudjowati, U. R., Yanuwiyadi, B., Sulistiono, R., \& Suyadi, R. (2013). Estimation of noise reduction by different vegetation type as a noise barrier: A survey in highway along Waru-Sidoarjo in East Java, Indonesia. International Journal of Engineering Science, 2(11), 20-25.

Rich, P. (1990). Characterizing plant canopies with hemispherical photographs. Remote Sensing Reviews, 5(1), 13-29. http://dx.doi.org/10.1080/02757259009532119.

Rowntree, R. A. (1998). Urban forest ecology: conceptual point of departure. Concepts in urban forest ecology. Journal of Arboriculture, 24(2), 62-71.

Sanusi, R., Johnstone, D., May, P., \& Livesley, S. (2017). Microclimate benefits that different street tree species provide to sidewalk pedestrians relate to differences in plant area index. Landscape and Urban Planning, 157, 502-511. http://dx.doi.org/10.1016/j.landurbplan.2016.08.010.

Smargiassi, A., Goldberg, M. S., Plante, C., Fournier, M., Baudouin, Y., \& Kosatsky, T. (2009). Variation of daily warns season mortality as a function of micro-urban het islands. Journal of Epidemiology and Community Health, 63(8), 659-664. PMid:19366997. http://dx.doi.org/10.1136/jech.2008.078147.

Statpoint Technologies INC. (2010). STATGRAPHICS $®$ Centurion XVI. Manual de usuario (305 p.)

Tang, Z., Ren, Z., Zheng, H., \& Xing-Yuan, H. (2017). Cooling effects of urban forest community structure. Ying Yong Sheng Tai Xue Bao, 28(9), 2823-2830.

Weiss, M., Baret, F., Smith, G., Jonckheere, I., \& Coppin, P. (2004). Review of methods for in situ leaf area index (LAI) determination Part II. Estimation of LAI, errors and sampling. Agricultural and Forest Meteorology, 121(1-2), 37-53. http://dx.doi.org/10.1016/j.agrformet.2003.08.001.

Authors' contributions: RI: Field work, Writing - original draft, data curation, Formal analysis; MPD: Conceptualization, Supervision, Field work, Formal analysis, Writing - original draft, Supervision, Writing - review \& editing; OVB: Methodology, Field work, Formal analysis; Writing - review \& editing. 